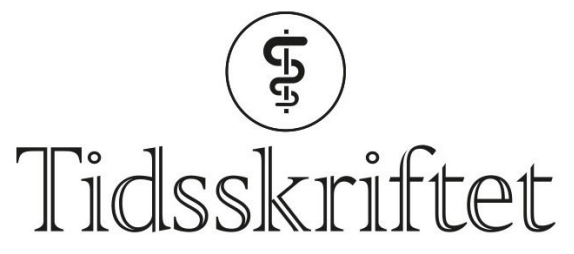

DEN NORSKE LEGEFORENING

\title{
Hukommelsestap under spinning
}

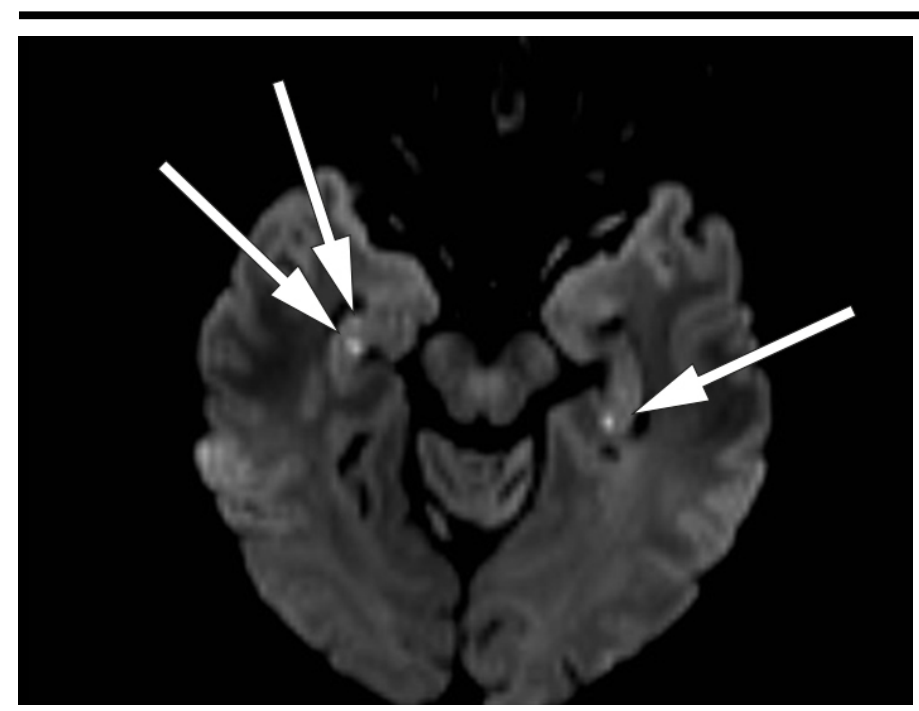

MEDISINEN I BILDER

\section{ELISABETH SYNNØVE NILSEN HUSEBYE}

E-post: elisabeth.synnove.nilsen.husebye@helse-bergen.no

Nevrologisk avdeling

Haukeland universitetssykehus

og

Klinisk institutt 1

Universitetet i Bergen

Elisabeth Synnøve Nilsen Husebye (f. 1989) er tidligere lege i spesialisering og nå stipendiat.

Forfatter har fylt ut ICMJE-skjemaet og oppgir ingen interessekonflikter.

\section{GUNNAR MOEN}

Radiologisk avdeling

Nevroradiologisk seksjon

Haukeland universitetssykehus

Gunnar Moen (f. 1958) er spesialist i radiologi/nevroradiologi.

Forfatter har fylt ut ICMJE-skjemaet og oppgir ingen interessekonflikter.

\section{ANETTE MARGRETHE STORSTEIN}

Nevrologisk avdeling

Haukeland universitetssykehus

Anette Margrethe Storstein (f. 1966) er spesialist i nevrologi og overlege dr.med.

Forfatter har fylt ut ICMJE-skjemaet og oppgir ingen interessekonflikter.

En kvinne i 6o-årene ble innlagt ved nevrologisk avdeling grunnet akutt retrograd og anterograd amnesi. Hun var i full jobb og frisk, 
bortsett fra medikamentelt behandlet hypertensjon. Symptomene debuterte under en spinningøkt. Hun stilte repeterende spørsmål og kunne ikke gjøre rede for hendelser samme dag eller ukene i forkant. Det var ingen fokalnevrologiske utfall ved nevrologisk undersøkelse. Tilstanden ble klinisk oppfattet som transitorisk global amnesi, og hun ble innlagt for observasjon. Det ble bestilt MR caput og EEG i differensialdiagnostisk øyemed. I løpet av de neste timene gikk symptomene gradvis tilbake. Dagen etter innleggelse var hun fullstendig restituert, men med et vedvarende hukommelsestap for noen timer den aktuelle dagen.

Transitorisk global amnesi er en godartet tilstand som medfører akutt, isolert forbigående anterograd amnesi, av og til med en retrograd komponent. Tilstanden rammer vanligvis personer i alderen 50-70 år. Årlig insidens hos personer over 50 år er 23,5 per 100000. Symptomene forsvinner spontant innen 24 timer og er ikke ledsaget av andre fokalnevrologiske symptomer eller redusert bevissthet. Ofte er tilstanden utløst av stress, hard fysisk anstrengelse eller kraftig emosjonell påkjenning.

Man har diskutert epileptogene, cerebrovaskulære eller migrenøse årsaksmekanismer, men patofysiologien er fortsatt usikker. Transitorisk global amnesi er en klinisk diagnose som er selvbegrensende og ikke krever spesifikk behandling. Utredning med MR og EEG er aktuelt ved atypisk sykehistorie og mistanke om annen årsak, og gjøres ofte ikke rutinemessig $(1,2)$.

Vår pasient hadde normalt EEG og normale blodprøver. MR caput på 3 Tesla-maskin viste normale forhold på ordinær diffusjonsvektet snittserie med $4 \mathrm{~mm}$ tykke snitt. På diffusjonsvektet snittserie med $2 \mathrm{~mm}$ snitt ble det funnet to punktformede diffusjonsavvik på hver side av samme dato svarende til hippocampus (bilde $1 \operatorname{og} 2$ ).

MR-funnene er typiske for transitorisk global amnesi. Da slike lesjoner er såpass små, lar de seg best påvise ved 3 Tesla MR-maskin med en snittprotokoll som omfatter tynne (2-3 mm), tette (snittavstand 2-3 mm) diffusjonsvektede snitt, der snittserien anlegges parallelt med hippocampusstrukturenes lengdeakse. Lesjonene lar seg lettest avdekke 48-72 timer etter symptomstart. Lesjonene er ikke spesifikke for transitorisk global amnesi, og påvisning av slike MR-forandringer kan føre til en feilaktig hjerneinfarktdiagnose. Det kliniske bildet er avgjørende for å skille tilstanden fra isolerte hippocampusinfarkt $(3,4)$.

Vår pasient hadde et klinisk bilde vel forenlig med transitorisk global amnesi, med ledsagende typiske lesjoner på MR-bildet. MR-bilder seks uker etter symptomdebut viste komplett tilbakegang av aktuelle lesjoner.

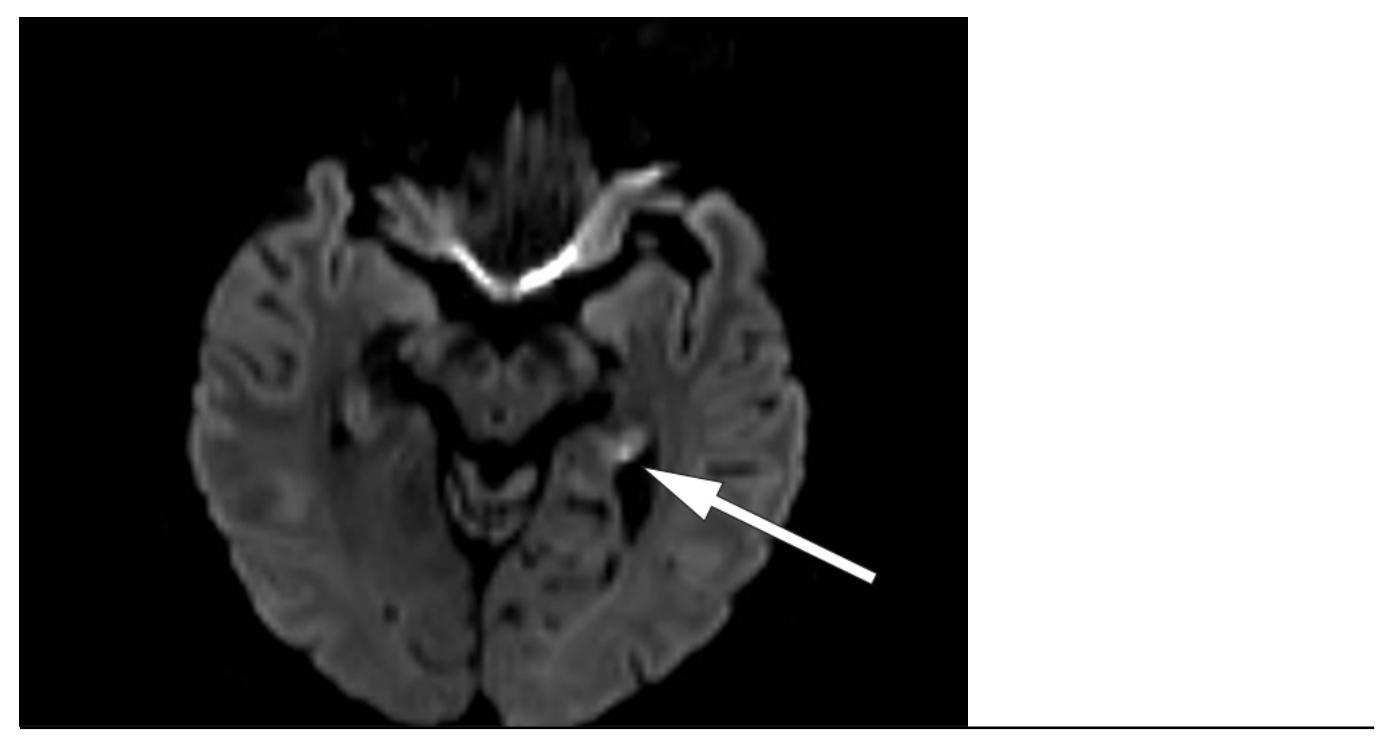


LITTERATUR:

1. Shekhar R. Transient global amnesia-a review. Int J Clin Pract 2008; 62: 939 - 42. [PubMed][CrossRef]

2. Arena JE, Rabinstein AA. Transient global amnesia. Mayo Clin Proc 2015; 90: 264 - 72.

[PubMed][CrossRef]

3. Bartsch T, Deuschl G. Transient global amnesia: functional anatomy and clinical implications. Lancet Neurol 2010; 9: 205-14. [PubMed][CrossRef]

4. Förster A, Al-Zghloul M, Wenz H et al. Isolated punctuate hippocampal infarction and transient global amnesia are indistinguishable by means of MRI. Int J Stroke 2017; 12: 292 - 6. [PubMed][CrossRef]

Publisert: 2. oktober 2017. Tidsskr Nor Legeforen. DOI: 10.4045/tidsskr.17.0177

Mottatt 22.2.2017, første revisjon innsendt 8.6.2017, godkjent 4.7.2017.

(C) Tidsskrift for Den norske legeforening 2020. Lastet ned fra tidsskriftet.no 